\title{
Meningen over het ideale co-assistentschap
}

\author{
G.R. Vink, D.R. Witte, E.J.S.M. Blenke, R.R. van Dijk
}

\section{Samenvatting}

Naar aanleiding van het nieuwe curriculum geneeskunde 1999 in Utrecht heeft de Co-raad onder Utrechtse co-assistenten een enquête gehouden over het ideale co-assistentschap. Als eerste kenmerk van een goed co-assistentschap noemden de co-assistenten (68\%) de mate van zelfstandig werken en verantwoordelijkheid. Dit item stond tevens bovenaan op de lijst van knelpunten bij de huidige co-assistentschappen. Co-assistenten willen naarmate hun co-assistentschappen vorderen steeds meer verantwoordelijkheid dragen en meer medische handelingen zelf uitvoeren. Om dit te bereiken hebben ze een goede begeleiding nodig met veel feedback (63\%). De begeleider moet een juiste attitude hebben ten opzichte van de coassistent en veel uitleg geven. Bovendien moet er goed, klinisch relevant onderwijs gegeven worden (65\%). Om een optimaal rendement te kunnen bereiken moet er een duidelijke taakomschrijving zijn en veel mogelijkheden voor patiëntencontacten (54\%). Co-assistentschappen die aan deze voorwaarden voldoen, worden door co-assistenten als goed en zeer leerzaam ervaren. (Vink GR, Witte DR, Blenke EJSM, Dijk RR van. Meningen over het ideale co-assisentschap. Tijdschrift voor Medisch Onderwijs 2000;19(5): 208-212.)

\section{Inleiding}

In Utrecht is in september 1999 een nieuw curriculum geneeskunde van start gegaan, waarin ook inhoud en vorm van de co-assistentschappen aangepast worden. ${ }^{1}$ De precieze invulling van de co-assistentschappen moet nog worden uitgewerkt. Uit de literatuur blijkt dat de begeleiding tijdens de co-assistentschappen een knelpunt is. Zo rapporteerden Scherpbier en Metz dat persoonlijke begeleiding en toezicht te wensen over lieten. ${ }^{2} \mathrm{Zij}$ stelden dat een degelijke begeleiding wel een noodzakelijke voorwaarde vormt voor een onderwijskundig verantwoord co-assistentschap. Ook Van der Gulden et al. constateerden dat er van persoonlijke aandacht voor de co-assistent in de praktijk maar weinig terechtkomt. ${ }^{3}$ Bij een enquête uitgevoerd door Sinke en Metz in Nijmegen kwamen als twee belangrijkste knelpunten naar voren het gebrek aan begeleiding en de te lange werktijden met als gevolg gebrek aan vrije tijd. ${ }^{4}$ Ook beide visitatiecommissies hebben veranderingen in de co-assistentschappen aanbevolen. 5 Voor de Utrechtse Co-raad, een groep co-assistenten die zich inzet voor de belangen van co-assistenten, vormden deze berichten uit de literatuur gekoppeld aan eigen ervaringen de aanleiding om bij de huidige co-assistenten na te gaan hoe voor hen het ideale co-assistentschap er uit zou zien.

\section{Methode}

Via een vragenlijst met open en invulvragen werd de mening van de co-assistenten over verschillende aspecten van de co-assistentschappen gevraagd. In open vragen werd de co-assistenten onder andere gevraagd kenmerken te geven van een goed co-assistentschap, een goede begeleider en goed onderwijs. Ook werd de co-assistenten gevraagd uit een lijst hun topvijf van knelpunten tijdens de co-assistent- 
schappen samen te stellen, waarbij ze eventueel knelpunten konden toevoegen. Verder werden enkele invulvragen over de co-assistentschappen gesteld. De vragenlijst werd tijdens het tweejaarlijkse symposium voor co-assistenten in Utrecht uitgedeeld. Er waren 176 co-assistenten bij dit symposium aanwezig. Aan het eind van de dag konden 83 ingevulde vragenlijsten in ontvangst worden genomen.

Tabel 1. Open vragen uit de enquête met de kenmerken die in antwoord daarop het vaakst genoemd werden. Bij elke vraag staat het percentage van de co-assistenten die de enquête invulden $(n=83)$ dat het betreffende kenmerk noemde.

Waardoor wordt een goed co-schap gekenmerkt?

$68 \%$ Veel verantwoordelijkheid en zelfstandigheid

$65 \%$ Goed onderwijs

63\% Goede begeleiding

$54 \%$ Goede taakomschrijving en organisatie

30\% Positieve houding t.o.v. co-assistent

17\% Goede beoordeling

\section{Wat zijn de kenmerken van een goede begeleider?}

$65 \%$ Juiste attitude

$52 \%$ Goed onderwijs/didactische vaardigheden

$38 \%$ Inzicht in taken en kennisniveau co-assistent

33\% Voldoende tijd/goede bereikbaarheid

33\% (Tussentijdse) evaluatie/kritische beoordeling

$25 \%$ Kunnen uitdagen en stimuleren

$12 \%$ Veel kennis

\section{Waardoor wordt goed onderwijs gekenmerkt?}

$75 \%$ Klinisch relevant

$45 \%$ Didactisch juist opgezet

$33 \%$ Interactief

$26 \%$ Goed georganiseerd

\section{Resultaten}

Uit de antwoorden op de open vraag over de kenmerken van een goed co-assistentschap komen vier belangrijke kenmerken naar voren (tabel 1). Verantwoordelijkheid en zelfstandigheid scoren het hoogste; dit wordt door $68 \%$ van de co-assistenten genoemd. Op de tweede plaats komt goed onderwijs (genoemd door $65 \%$ ). Een goede begeleiding wordt aangegeven door $63 \%$ van de co-assistenten en een goede taakomschrijving en organisatie door 54\%. Op deze kenmerken wordt achtereenvolgens nader ingegaan.

\section{Verantwoordelijkheid en zelfstandigheid}

Een moeilijk punt tijdens de co-assistentschappen vormen de hoeveelheid verantwoordelijkheid die een co-assistent mag dragen, en de mate van zelfstandig werken. Vooral na het doorlopen van de eerste paar co-assistentschappen, of na een aantal weken op dezelfde afdeling gewerkt te hebben, stellen veel co-assistenten een gedoseerde mate van verantwoordelijkheid op prijs. Ook verwachten zij steeds meer medische handelingen zelf uit te mogen voeren en steeds zelfstandiger te mogen werken. Eigen patiënten voor wie in overleg met de supervisor een beleid wordt uitgestippeld, worden vaak genoemd als mogelijke verbetering. Dat het niet eenvoudig is om dit te realiseren, is ook duidelijk. Per co-assistent zal immers gekeken moeten worden hoeveel verantwoordelijkheid hij of zij aankan.

\section{Onderwijs}

Als antwoord op de invulvraag "het onderwijs tijdens de co-assistentschappen is (te)....." vulde $60.3 \%$ van de co-assistenten in dat er te weinig onderwijs wordt gegeven. Het onderwijs dat gegeven wordt, is vaak slecht georganiseerd, vindt $20.7 \%$. Het onderwijs valt te vaak uit en is weinig gestructureerd. Ook wordt opgemerkt 
door $8.6 \%$ van de co-assistenten dat het onderwijs slecht aansluit op de ervaringen in de kliniek. Slechts $6.9 \%$ van de co-assistenten vindt het onderwijs goed.

Uit de antwoorden op de open vraag over de kenmerken van goed onderwijs komt een aantal belangrijke kenmerken naar voren. Klinische relevantie scoort het hoogst (tabel 1). Hierbij wordt gezegd dat het onderwijs praktisch moet zijn, zodat de nieuw opgedane kennis direct toepasbaar is op de desbetreffende afdeling. Vormen van onderwijs die als verbetering opgevat worden, zijn bedside teaching en onderwijs aan de hand van een casus. Het onderwijs zou volgens de co-assistenten gericht moeten zijn op van tevoren vastgestelde eindtermen. Naast klinisch relevant zou het onderwijs ook didactisch juist opgezet moeten zijn, met veel up-to-date informatie. Er zou sprake moeten zijn van inbreng van de kant van de co-assistenten en tijd voor vragen. Het onderwijs moet dus interactief zijn. Bovendien moet het goed georganiseerd zijn. Docenten moeten immers weten wanneer en waarover ze onderwijs moeten geven. Ook moet de docent ervoor zorgen dat onderwijs en de patiëntenzorgtaken niet dubbel geroosterd zijn, zodat er geen onderwijs uitvalt en zij niet gestoord worden door pieper of telefoon.

\section{Begeleiding}

Goede begeleiding kan een co-assistentschap maken of breken. Voor de co-assistenten blijkt een juiste attitude het belangrijkste kenmerk van een goede opleider te zijn (tabel 1). De opleider moet het leuk vinden een co-assistent te begeleiden, enthousiast zijn en interesse tonen voor de co-assistent. Veel co-assistenten gaven aan dat ze graag door de opleider meer betrokken zouden worden bij het werk op de afdeling. Ook gaven ze aan, dat een opleider over didactische vaardig- heden moet beschikken en goed onderwijs moet kunnen geven. Hij of zij zou veel tijd moeten besteden aan uitleg en bedside teaching en hierbij oog moeten hebben voor de voorkennis van de co-assistent. De opleider zou de co-assistent een bepaalde mate van zelfstandigheid en eigen verantwoordelijkheid moeten durven geven. Een belangrijke voorwaarde om aan bovenstaande punten te kunnen voldoen, is volgens de co-assistenten dat een opleider voldoende tijd heeft voor de begeleiding en dat hij bereikbaar is. Ook een tussentijdse evaluatie, waarbij de coassistent feedback krijgt en eventueel wordt bijgestuurd, wordt als zeer positief ervaren. Hierop zou dan uiteindelijk een kritische eindbeoordeling moeten volgen. Een opleider die een co-assistent kan stimuleren en uitdagen om dingen zelfstandig na te zoeken en die de passie voor zijn vak over kan brengen, wordt gewaardeerd. Ten slotte wordt door maar 12\% van de co-assistenten naar voren gebracht dat de opleider zelf veel kennis paraat moet hebben.

\section{Taakomschrijving en organisatie}

Bij de kenmerken van een goed co-assistentschap wordt op de vierde plaats door de co-assistenten een duidelijke taakomschrijving en een goede organisatie genoemd. Bij het begin van elk co-assistentschap scheelt het veel tijd en onduidelijkheid als de co-assistent goed ingewerkt wordt. Inlichtingen over de precieze taken op de desbetreffende afdeling en een duidelijk rooster met alle overleg- en onderwijsbijeenkomsten worden zeer op prijs gesteld. Tevens zou informatie over de hoeveelheid te lopen diensten en de compensatieregelingen beschikbaar moeten zijn.

Een groot aanbod aan nieuwe patiënten op de polikliniek, die door de co-assistenten gezien kunnen worden, voldoende op- 
names en veel mogelijkheden tot patiëntencontact worden door de co-assistenten belangrijk gevonden. Dit lijkt alleen gegarandeerd te kunnen worden als er niet te veel co-assistenten op een afdeling geplaatst worden.

\section{Probleem topvijf}

Om de grootste knelpunten tijdens de huidige co-assistentschappen te kunnen signaleren, hebben wij de co-assistenten gevraagd een topvijf van de grootste knelpunten samen te stellen (tabel 2). Op de eerste plaats wordt te weinig verantwoordelijkheid genoemd. Het is opvallend dat verantwoordelijkheid ook het vaakst genoemd wordt als kenmerk van een goed co-assistentschap.

Ook in de antwoorden op de vraag wat co-assistenten het eerst aan de co-assistentschappen zouden willen veranderen, komt weer een aantal punten naar voren dat genoemd is als kenmerk van een goed co-assistentschap (tabel 2). De werktijden, de compensatiemogelijkheden voor de diensten, het onderwijs en de begeleiding zijn volgens veel co-assistenten voor verbetering vatbaar. Het is opvallend dat

Tabel 2. Lijst met knelpunten waaruit de co-assistenten een topvijf konden samenstellen. De topvijf staat aangegeven in de linkerkolom.

2 Te weinig te doen

Te veel klussen

Een te lange werkweek

3 Te weinig begeleiding

1 Te weinig verantwoordelijkheid Te veel verantwoordelijkheid

4 Te weinig onderwijs

5 De beoordeling

Te weinig afwisseling gedurende een co-schap Anders, nl.
Tabel 3. Antwoorden uit de enquête met het percentage van de geënquêteerde co-assistenten $(n=83)$ dat het betreffende antwoord invulde bij de vraag "Het eerste wat ik aan de co-assistentschappen zou willen veranderen is".

\begin{tabular}{ll}
\hline $34 \%$ & Betere organisatie (betere werktijden) \\
$26 \%$ & Beter onderwijs en begeleiding \\
$14 \%$ & Meer zelfstandigheid \\
$8 \%$ & Betere beoordeling \\
$8 \%$ & Betere positie \\
$6 \%$ & Betere geldelijke vergoeding \\
$4 \%$ & Niets \\
\hline
\end{tabular}

slechts $4 \%$ van de co-assistenten aangeeft niets aan de co-assistentschappen te willen veranderen.

\section{Conclusie}

De Utrechtse co-assistenten blijken duidelijke meningen te hebben over het ideale co-assistentschap. Het eerste punt is de mate van verantwoordelijkheid en zelfstandig werken. Co-assistenten willen naarmate hun co-assistentschappen vorderen steeds meer verantwoordelijkheid dragen, zodat er op een gegeven moment een geleidelijke overgang is naar het werken als arts-assistent. Om dit doel te bereiken willen ze een goede begeleiding met veel feedback. De begeleider moet een juiste attitude hebben ten opzichte van de co-assistent en veel uitleg en onderwijs geven. Dit onderwijs moet klinisch relevant zijn en direct toepasbaar. Het lijkt ons een uitdaging voor het nieuwe curriculum om de co-assistentschappen zo in te richten, dat in de toekomst aan voorwaarden voor goed klinisch onderwijs voldaan kan worden. 


\section{Literatuur}

1. Blauwdruk I nieuw curriculum Utrecht. Utrecht: Opleidingsbestuur; 1998.

2. Scherpbier AJJA, Metz JCM. Co-assistentschap: een stage? Bulletin Medisch Onderwijs 1989;2:64-6.

3. Gulden JWJ van der, Bulte JA, Metz JCM. Vragen bij het onderwijs aan co-assistenten. Ned Tijdschr Geneeskd 1989;133:564-7.

4. Sinke E, Metz JCM. Begeleiding van co-assistenten. Bulletin Medisch Onderwijs 1989;8:132-9.

5. Vereniging van Samenwerkende Nederlandse Universiteiten. Visitatierapport geneeskunde en gezondheidswetenschappen. Utrecht: Vereniging van Samenwerkende Nederlandse Universiteiten; 1992.

\section{Summary}

On the occasion of the start of the new undergraduate medical curriculum of Utrecht Medical School in September 1999, the Utrecht council of clinical clerks surveyed clinical clerks about the quality of the clerkship experience. The most important characteristic of a good clerkship, mentioned by $68 \%$ of the respondents is for students to be in charge of patients and to be able to work independently. The absence of responsibility and lack of opportunities to work independently came also first on the list of barriers to a good clerkship. Good supervision with extensive feedback was the second most frequently mentioned characteristic of a good clerkship (63\% of respondents). The supervisor should have a positive attitude towards students and be willing to give detailed instruction. Good teaching relevant to the domain of the clerkship rotation concerned was mentioned by $65 \%$, and $54 \%$ desired a clear job description and many patient contacts. Clerkships that meet these conditions will be experienced by the students as highly instructive and of excellent quality. (Vink GR, Witte DR, Blenke EJSM, Dijk RR van. The ideal clerkship. Dutch Journal of Medical Education 2000;19(5): 208-212.)
6. VSNU-Visitatiecommissie Geneeskunde en Gezondheidswetenschappen. Onderwijsvisitatie geneeskunde en gezondheidswetenschappen Utrecht: Vereniging van Samenwerkende Nederlandse Universiteiten; 1997.

G.R. Vink, D.R. Witte, E.J.S.M. Blenke, R.R. van Dijk zijn allen co-assistent in het Universitair Medisch

Correspondentieadres:

G.R. Vink, Gildstraat 109, 3572 EL Utrecht, geraldinevvink@hotmail.com 